\title{
Perinatal outcome of patients with placenta percreata
}

\section{Plasenta perkreatalı hastaların perinatal sonuçları}

\author{
Erkan ELCI ${ }^{1}$, Sena SAYAN ${ }^{2}$, Gulhan ELCI ${ }^{3}$, Numan CIM ${ }^{4}$
}

\begin{abstract}
Aim: Placental invasion anomalies are rare, but it causes serious fetomaternal morbidity and mortality. In our study, we aimed to evaluate the fetomaternal results of cases with Abnormal Invasive Placenta ( Placenta Percreata).

Methods: Patients who underwent a peripartum hysterectomy or whose placenta was left in uterin cavity due to placenta percreata in our hospital were retrospectively analyzed. Data of 20 patients were noted.

Results: The mean age of the patients was \pm SD (min-max) $33 \pm 5,704(25-46)$ and $60 \%(n=12)$ of the patients had additional diseases. Fifty five percent of patients $(n=11)$ were operated in emergency conditions and $45 \%$ ( $n$ $=9)$ in elective conditions. Surgical complications were $65 \%(n=13)$ bladder injuries, $30 \%(n=6)$ disseminated intravascular coagulation (DIC), $20 \%(n=4)$ infection, $15 \%(n=3)$ relapartomy and $5 \%(n=1)$ was pulmonary embolism. Mortality increased three times (OR; 3.003 (95\% CI, 0.372-24.390) in patients with a comorbidity while 4.7 times $(\mathrm{OR} ; 4.784)$ in emergency operations. Operations under elective conditions and previously ultrasonographic diagnosis (Odd ratio values ; 0,219 (95\% CI, 0,021-2,447) and 0,615 (95\% CI, 0,043-8,695) recpectively) decreased maternal mortality.

Conclusion: Prenatal diagnosis and performing elective surgeries in percreata cases are important to reduce maternal mortality. Although there are various surgical complications, we think that DIC development is important in mortality and massive transfusion does not decrease the mortality.
\end{abstract}

Keywords: Recurrent caesarean, hysterectomy, placenta percreata

Öz

Amaç: Plasenta invazyon anomalileri nadir görülmesine rağmen ciddi fetometarnal morbidite ve mortaliteye sebep olmaktadır. Çalışmamızda plasenta invazyon anomalisi olan olguların perinatal sonuçlarını değerlendirmeyi amaçladık.

Yöntemler: Hastanemizde 2012-2014 tarihleri arasında peripartum histerektomi yapılan ve intraoperati plasentası uterin kavitede bırakılan hastalar retrospektif olarak incelendi. 20 hastanın verileri not edildi.

Bulgular: Hastaların yaş ortalamaları \pm SD (min-max) $33 \pm 5,704$. (25-46) saptandı. Hastaların \% 60’ında $(n=12)$ ek hastalıklar da vardı. Hastaların \% 55'i $(n=11)$ acil șartlarda ve \% 45'i $(n=9)$ elektif şartlarda opere edildi. Perkreta operasyonlarında oluşan cerrahi komplikasyonlar sıklığına göre sırasıyla \% 65(n=13) mesane yaralanması, \% $30(n=6)$ dissemine intravaskülar kuagulasion (DIC), \% $20(n=4)$ enfeksiyöz komplikasyonlar ve $\% 5(\mathrm{n}=1)$ pulmoner emboli şeklindeydi. Maternal mortalite riskinin ek hastalığı olan hastalarda 3 kat (OR; 3,003 (95\%CI, 0,372-24,390) ve acil şartlarda ameliyat olan hastalarda 4,7 kat (OR;4,784 (95\%CI, 0,408 47,619) artığı saptandı. Hastaların elektif şartlarda ameliyat olması ve önceden ultrasonografik olarak tanı almış olmalarının da (OR; 0,219 (95\%CI, 0,021-2,447), OR; 0,615 (95\%CI, 0,043-8,695) maternal mortalite riskini azalttığı saptandı. Korelasyon analizinde maternal mortalite ile maternal yaş $(0,473, p=0,035)$ ve masive kan transfüzyonunun $(0,562, \mathrm{p}=0,010)$ pozitif korelasyon, postoperatif hemoglobin değeri ile de negatif kolerasyon gösterdiği saptanmıştır $(-0,723, \mathrm{p}=0,010)$.

Sonuç: Plasenta perkreatalı hastalarda, prenatal tanı konulmuş olması ve hastaların elektif şartlarda opere edilmesi maternal mortalite riskinin azaltılması açısından önem arz etmektedir. Çeşitli cerrahi komplikasyonla olmasına rağmen DIC tablosu mortalite açısından önemlidir ve bu tabloda masif transfüzyon da mortaliteyi azaltmamaktadır.

Anahtar Kelimeler: Tekrarlayan sezaryen, histerektomi, plasenta perkreata
1 University of Health Sciences, Umraniye Training and Research Hospital, Department of Obstetrics and Gynecology, Istanbul, Turkey 2 Marmara University, Faculty of Medicine, Department of Obstetrics and Gynecology, Istanbul, Turkey

3 University of Health Sciences, Sancaktepe Training and Research Hospital, Department of Obstetrics and Gynecology, Istanbul, Turkey

${ }^{4}$ Istanbul Bilim University, School of Medicine, Department of Obstetrics and Gynecology, Istanbul, Turkey

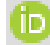

SS: 0000-0001-6758-1127

GE: 0000-0003-2350-2567

NÇ: 0000-0003-0983-3204

Ethics Committee Approval: The study was approved by Yüzüncü Yil University Faculty of Medicine Ethical Committee (07)-28/05/14

Etik Kurul Onayı: Bu çalıșma Yüzüncü Y1l Üniversitesi Tıp Fakültesi etik kurulundan onay almıştır (07)-28/05/14

Conflict of Interest: No conflict of interest was declared by the authors.

Cıkar Catıșması: Yazar çıkar çatısması bildirmemiştir.

Financial Disclosure: The authors declared that this study has received no financial support.

Finansal Destek: Yazarlar bu calıșma için finansa destek almadıklarını beyan etmişlerdir.

Gelis Tarihi / Received: 12.07.2020

Kabul Tarihi / Accepted: 23.11.2020

Yayın Tarihi / Published: 15.12.202

Sorumlu yazar / Corresponding author:

Erkan Elçi

Adres/Address: Adem Yavuz, Str No 01, Elmalıkent, 34070, Umraniye, Istanbul, Turkey e-posta: dr.erkanelci@gmail.com

Tel/Phone: +905304036977

Copyright $(\mathrm{C}$ ACEM 


\section{Introduction}

Abnormal Invasive Placenta (AIP) is a life-threatening condition. It is associated with maternal and fetal morbidity and mortality [1]. According to the degree of this abnormal trophoblastic infestation, there are three variants: acreta (after the decidual layer), increta (invasion into myometrium) and percreta (myometrium, uterine serosa, and adjacent tissue invasion) [2]. In general, these invasion anomalies are called placenta acreta. In the current review, placenta acreta ranges between 1 in 100 and 1 in 10,000 [3]. The incidence of placental invasion anomaly has increased 10 times in the last 50 years with the frequency of cesarean (C / S) [4]. In some middle-income countries such as Egypt, Turkey, Mexico, Brazil more than half of the births were achieved by elective C/S [5]. This suggests that in these countries AIP-related mortality and morbidity will increase in the future.

We aimed to retrospectively analyze fetomaternal mortality and morbidity in placenta acreta cases encountered due to the high birth rates in our clinic.

\section{Material and methods}

In this study, 20 patients who underwent peripartum hysterectomy diagnosed with placenta percreata or left in the uterine cavity between 2010 and 2014 in our hospital were retrospectively analyzed. This study conforms with the principles of the 2008 Declaration of Helsinki and written informed consent was obtained from the patient or the patient's legal guardians(Ethics committee approval:(07)-28/05/14).

The demographic characteristics of the patients, age, gravida and parity, gestational week, previous $\mathrm{C} / \mathrm{S}$ history, previous uterine surgery, the condition of the placenta in the current pregnancy, complaints during admission to the hospital, hospitalization time, intensive care hospitalization time, newborn weight and APGAR score were noted. Abdominal and uterine incision type, hypogastric artery ligation (HAL), complications during the operation, postoperative complications, erythrocyte transfusion, and fresh frozen plasma (FFP), maternal and fetal mortality and morbidity were noted.

Post-operative pathology results were examined. Transabdominal and transvaginal ultrasonography and doppler ultrasonography were used to evaluate the placenta position and degree of invasion. For elective cases, 6 units (U) erythrocyte suspension (ES) and 6 units (U) FFP were prepared before the operation. In elective cases, a midline abdominal incision and a fundal median incision were frequently used. Afterwards, the umbilical cord was clamped. The placenta was left in place and the bladder dissection started. A total hysterectomy (TAH) was performed in those with previa totalis and an inferiorly located placenta. A subtotal hysterectomy (SAH) was performed in cases with a low invasion surface and a placental location far from the cervix. HAL was only performed in patients with prolonged bleeding time, intraoperative excess bleeding, or with a high possibility of reoperation, intraoperative transfusion, and patients who were operated for the second time. In cases where bladder dissection was not performed completely, the bladder was perforated by the surgeon, and dissection was continued. If required, a urology consultation was requested and a double $\mathrm{J}$ catheter was inserted into the ureters from the bladder. A drain was placed in all cases. The patients were taken to the adult intensive care unit, if necessary, according to the assessment of the anesthesiologist.

A conservative approach was made to a single case with a previous $\mathrm{C} / \mathrm{S}$ history and ultrasonographically diagnosed in the prenatal period. The placental cord was clamped and HAL was performed due to abundant organ invasion in the abdomen. The bladder could not be reached and the surgery was discontinued. Metotrexate was then planned to be applied.

\section{Statistical Analysis}

In this study, statistical analysis was performed with SPSS 22 software (IBM Corp., Armonk, NY, USA). Descriptive statistics of data were expressed with average \pm standard deviation, median and other statistics using the explore option in SPSS. maternal mortality odds ratio rates were estimated. Spearman's correlation was used to determine how the mortality is affected by other values. Uncertainty was expressed as a $95 \%$ confidence interval (CI). $\mathrm{P}<0.05$ was considered statistically significant.

\section{Results}

In our hospital, 5263 birth deliveries were recorded. $1217(\% 23,1)$ of these patients were delivered by C/S. 623 $(\% 51,1)$ of the $\mathrm{C} / \mathrm{S}$ deliveries had a C/S history. Twenty of these patients were diagnosed with placenta percreata intraoperatively or after their hysterectomy. Cases without a pathology sample and placenta in the uterine cavity were not considered as placenta percreata.

Table 1. Demographic characteristics of patients, risk factors, maternal and fetal outcomes

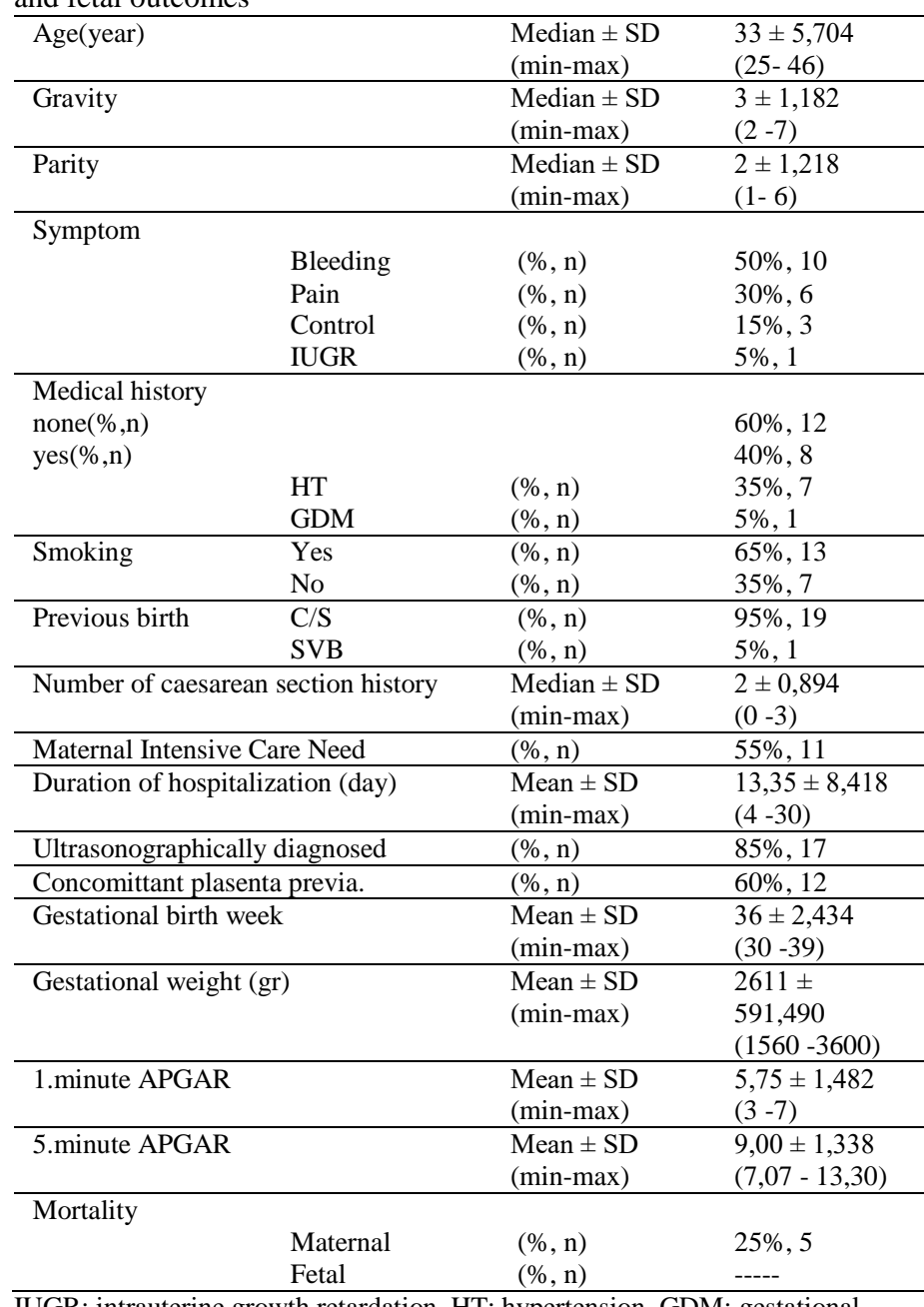

IUGR: intrauterine growth retardation, HT: hypertension, GDM: gestational diabetes mellitus, C/S: cesarean section, SVB:spontaneous vaginal birth

Table 1 summarizes the demographic characteristics, risk factors, maternal, and fetal outcomes of the patients. Mean age, gravida, parity values of the patients were \pm SD (min-max) $33 \pm 5,704$ (25-46), $3 \pm 1,182(2-7), 2 \pm 1,218$ (1-6), respectively. The complaints of the patients for rehospitalisation and readmission were noted as $50 \%$ bleeding, $30 \%$ pain, $15 \%$ control 
and 5\% Intra Uterin Growth Retardation (IUGR). Sixty percent of patients had an additional disease. Hypertension (35\%) was the most common in these patients as an additional disease. Except for one patient, previous deliveries were carried out by cesarean method $(95 \%, \mathrm{n}=19)$. After the operation, $55 \%$ of the patients needed intensive care. The average duration of hospitalization of operated patients was $13.35 \pm 8.418$ days, and $25 \%$ of the patients died during their follow-up. A prenatal diagnosis could be made in $85 \%$ of the patients by ultrasonography. Although $15 \%$ of patients had AIP, the diagnosis could not be made (Table 1). Placenta previa totalis was accompanied by $60 \%$ of the patients. The mean ultrasonographic gestational week was determined mean \pm SD (min-max) $36 \pm 2,434$ (30-39). In terms of fetal results; a birth weight mean \pm SD (min-max) $2611 \pm 591,490$ (1560-3600), 1st minute APGAR Mean \pm SD (min-max) $5.75 \pm 1.482$ (3-7), 5th minute APGAR mean \pm SD ( min-max) $9.00 \pm 1.338$ (7.0713.30) was detected and fetal mortality was not observed.

Table 2. Pre-operative, intra-operative and post-operative patient data Operation

\begin{tabular}{cl} 
emergency $(\%, \mathrm{n})$ & $55 \%, 11$ \\
elective $(\%, \mathrm{n})$ & $45 \%, 9$ \\
\hline Skin incision & $30 \%, 6$ \\
pfannenstiel $(\%, \mathrm{n})$ & $55 \%, 11$ \\
infraumblical(\%,n) & $15 \%, 3$
\end{tabular}
infraumblical $(\%, \mathrm{n})$

Uterine Incision

\begin{tabular}{cl}
$\begin{array}{l}\text { Uterine } \\
\text { fundal vertical }(\%, \mathrm{n})\end{array}$ & $80 \%, 16$ \\
kerr incision $(\%, \mathrm{n})$ & $20 \%, 4$ \\
\hline Treatment & $85 \%, 17$ \\
TAH $(\%, \mathrm{n})$ & $10 \%, 2$ \\
Subtotal TAH $(\%, \mathrm{n})$ & $5 \%, 1$ \\
MTX $(\%, \mathrm{n})$ &
\end{tabular}

$\operatorname{HAL}(\%, \mathrm{n})$

yes $60 \%, 12$

no

$40 \%, 8$

Surgical complications

Bladder injury $(\%, \mathrm{n}) \quad 65 \%, 13$

Infection $(\%, \mathrm{n}) \quad 20 \%, 4$

DIC $(\%, \mathrm{n}) \quad 30 \%, 6$

Relaparotomy $(\%, \mathrm{n}) \quad 15 \%, 3$

pulmonary embolism $(\%, \mathrm{n}) \quad 5 \%, 1$

Adjacent organ invasion $60 \%, 12$

Operation duration ( minute)

mean \pm SD

$192,50 \pm 52,468$

(min-max)

$(110-240)$

Intraoperative consultation $(\%, \mathrm{n})$

$55 \%, 11$

Blood transfusion (number of patients) $(\%, \mathrm{n})$

$\begin{array}{ll}\text { yes } & 85 \%, 17 \\ \text { no } & 15 \%, 3\end{array}$

Erytrocyte Suspension Transfusion

$\begin{array}{ll}\text { Median } \pm \text { SD } & 4,5 \pm 3,44 \\ (\min -\max ) & (0-13)\end{array}$

FFP transfusion

Median \pm SD $\quad 4,5 \pm 4,48$

$(\min -\max ) \quad(0-16)$

Pre-op HGB (gr/dl)

Mean \pm SD

$10,70 \pm 1,490$

(min-max)

$(7,07-13,30)$

\begin{tabular}{cl}
\hline Intra-op HGB $\quad(\mathrm{gr} / \mathrm{dl})$ & \\
$\begin{array}{l}\text { Mean } \pm \text { SD } \\
(\min -\max )\end{array}$ & $\begin{array}{l}8,50 \pm 1,173 \\
(6,50-10,50)\end{array}$ \\
\hline Post-op HGB (gr/dl) & \\
Mean \pm SD \\
(min-max)
\end{tabular}

MTX: Methotrexate, TAH: Total abdominal Hysterectomy, HAL: Hypogastric artery

ligation, FFP: Fresh frozen plasma, ICU: Intensive care unit, USG: Ultrasonography, DIC:

Disseminated Intravascular Coagulalopathy, HGB: hemoglobin, Pre-op:Before oparation,

Post-op:After oparation
Pre-operative (preop), intra-operative (inop) and postoperative (postop) patient data are summarized in Table $2.55 \%$ of the patients were operated under emergency conditions and $45 \%$ were operated under elective conditions. Abdominal incision was infraumblical (IU) in $55 \%$ of patients, pfannenstiel (PNS) in $30 \%$ and supraumblical (SU) + infraumblical (IU) in $15 \%$ chosen. During the operation, $85 \%$ Total abdominal Hysterectomy (TAH), 10\% SAH were performed. Methotrexate (MTX) treatment was deemed suitable as a conservative method because one patient had advanced adjacent tissue invasion. Adjacent organ invasion was observed in $60 \%$ of the patients. HAL was performed in $60 \%$ of patients with high bleeding probability and low intraoperative haemoglobin (HGB) Value. Surgical complications were $65 \%$ bladder injury, $30 \%$ disseminated intravascular coagulation (DIC), $20 \%$ infection, $15 \%$ relaparatomy and $5 \%$ was pulmonary embolism. The operation time was mean \pm SD (min-max) $192.50 \pm 52.468$ (110240) minutes. Intraoperative consultation (urology, cardiovascular surgery and general surgery) was requested in $55 \%$ cases during the operation. Blood and blood product transfusions were performed in $85 \%$ of the patients. Transfused ES amount was mean \pm SD (min-max) $4.5 \pm 3.44(0-13)$ and FFP amount was mean $\pm \mathrm{SD}(\min -\max ) 4.5 \pm 4.48(0-16)$.

Table 3. Odds ratio rates between maternal mortality and other variables

\begin{tabular}{lll} 
& Mortality & Odd ratio (OR) $(95 \% \mathrm{CI})$ \\
\hline $\begin{array}{lll}\text { HAL (hypogastric arter } \\
\text { ligation) }\end{array}$ & + & $3,496(95 \% \mathrm{CI}, 0,312-$ \\
& & $38,461)$ \\
\hline Smoking & + & $2,666(95 \% \mathrm{CI}, 0,236-$ \\
& & $30,303)$ \\
\hline $\begin{array}{l}\text { Adjacent tissue } \\
\text { invasion }\end{array}$ & + & $3,496(95 \% \mathrm{CI}, 0,312-$ \\
\hline Additional disease & + & $38,461)$ \\
& & $3,003(95 \% \mathrm{CI}, 0,372-$ \\
& $24,390)$ \\
\hline Emergency operation & + & $4,784(95 \% \mathrm{CI}, 0,408-$ \\
& & $47,619)$ \\
\hline Elective operation & + & $0,219(95 \% \mathrm{CI}, 0,021-$ \\
& & $2,447)$ \\
\hline Ultrasonographic & + & $0,615(95 \% \mathrm{CI}, 0,043-$ \\
preliminary diagnosis & & $8,695)$ \\
\hline
\end{tabular}

Table 3 shows maternal mortality odds ratio values between maternal mortality and other variables. Mortality increased, 3.4 times with adjacent organ invasion (OR; 3.496 (95\% CI, 0.312-38.461), 2.6 times if the patient was smoking (OR; 2.666 (95\% CI, 0.236-30.303) and 3 times if the patient had a additional disease (OR ; 3,003 (95\% CI, 0,372-24,390), 4,7 times (OR; 4,784 (95\% CI, 0,408-47,619) in emergency surgery and 3.4 times (OR; 3,496 (95\% CI, 0,312) in patients undergoing HAL -38,461)) increases. Although HAL seems to increase mortality, patients undergoing HAL are those with increased bleeding, prolonged surgery, and operated for the second time. The elective operations (OR: 0,219 (95\% CI, 0,021-2,447)) and prior ultrasonographic diagnosis (OR: 0,615 (95\% CI, 0,043$8,695)$ reduce maternal mortality. Table 4 summarizes the correlation between maternal mortality and (HGB) values, hospitalization, maternal age, and gestational week. There was a statistically significant correlation between maternal mortality and other variables between maternal age $(\mathrm{p}=0.035)$, massive blood transfusion $(\mathrm{p}=0.010)$, and negative correlation between post-op (HGB) value $(\mathrm{p}=0.010)$. Demographic and operational characteristics of five cases with mortality and data of complications are summarized in Table 5. 
Table 4. Correlation between maternal mortality and hemoglobine values, hospitaliation, maternal age and gestational week.

\begin{tabular}{lll} 
& Mortality & $\mathrm{p}$ \\
\hline Age (years) & $0,473^{*}$ & $0,035^{*}$ \\
\hline Gravida & 0,053 & 0,804 \\
\hline Gestational week & 0,365 & 0,113 \\
\hline $\begin{array}{l}\text { Preoperative hgb } \\
\text { (gr/dl) }\end{array}$ & $-0,010$ & 0,967 \\
\hline $\begin{array}{l}\text { Intraoperative hgb } \\
\text { (gr/dl) }\end{array}$ & $-0,060$ & 0,800 \\
\hline $\begin{array}{l}\text { Postoperative hgb } \\
\text { (gr/dl) }\end{array}$ & $-0,723^{*}$ & $0,010^{*}$ \\
\hline Operation time & 0,243 & 0,301 \\
\hline Length of hospital stay & 0,443 & 0,051 \\
\hline Transfusion of ES & $0,562^{*}$ & $0,010^{*}$ \\
\hline
\end{tabular}

* Statistical significance was defined as $\mathrm{p}<0.05$, ES:Erythrocyte Transfusion

\section{Discussion}

It is reported that the rate of maternal mortality due to AIP can vary between $3 \%$ and $10 \%$ [6]. In the region where our study was conducted, maternal deaths were reported as 20.1 per 100,000 births and 43 deaths in the year of our study. Five of these deaths are as high as AIP related death and $11 \%$ of maternal deaths [7]. Placenta previa, advanced maternal age, multiparity and some uterine interventions have been associated with the incidence of placenta percreata [8]. In addition, the incidence of placental location abnormalities has been shown to increase from $11 \%$ to $67 \%$ in relation to the number of previous $\mathrm{C} / \mathrm{S}$ [9]. In $95 \%$ of our cases, delivery was previously performed by $\mathrm{C} / \mathrm{S}$, only one patient was diagnosed with percreata after NVD, but the patient had a history of curettage. According to average age $(33 \pm 5,704(25-46))$, there is a statistically significant positive correlation between maternal mortality and age $(0.447, p=0.035)$. Sixty percent of our cases were accompanied by placenta previa

In the literature, TAH is frequently preferred in treatment, since placenta percreta is associated with placenta previa in most cases and the placenta occupies the lower segment of the uterus [10]. However, it has been reported that performing SAH has many advantages such as fewer injuries to the adjacent organs, less blood loss, and shorter operation time and hospitalization [10]. In our clinic, primarily the SAH or TAH approach is preferred. However, the approach may vary according to the fertility request or surgical difficulty. TAH was performed in $85 \%$ of our cases while $\mathrm{SAH}$ was performed in $10 \%$. Conservative treatment was planned in only one case due to advanced tissue invasion.

On the other hand, there are also conservative approaches. Intrauterine balloon inflation, methotrexate therapy, uterine, and internal iliac artery ligation, and selective arterial embolization have been described without performing a hysterectomy [11,12]. Furthermore, positive results have been reported in patients with segmental resection of the uterus anterior wall with placenta percreta in selected cases. However, it has been reported that this is not possible for every case that can be determined intraoperatively [13]. In our study, only one case was approached conservatively and an infection developed during the follow-up. In this case, the placenta was completely left inside the uterus, and HAL was performed and Methotrexate was applied. Although the patient received long-term antibiotic therapy, the infection developed. A cure was achieved after 9 months.

It has been reported that HAL has no effect on reducing morbidity, estimated blood loss, and blood transfusion needs $[14,15]$. The mortality rate of patients with adjacent organ invasion with placenta percreta has been reported to be $7 \%$ [16]. We are not doing HAL in all of our cases. However, in cases of prolonged bleeding, prolonged cases, and patients who had been operated for the 2nd time, the HAL operation was performed. This may be the reason for increased maternal mortality in patients with HAL (OR; 3,496).

Complications include bleeding and extensive intravascular coagulation (DIC) development, kidney failure, acute respiratory distress syndrome, infection and bladder, ureter, and / or intestinal injuries [17]. It is emphasized that placing catheters to the ureters reduces the risk of ureteral injury before surgery, and this procedure does not prevent complete injury [18]. Surgical complications seen in our cases were $65 \%$ bladder injury, 30\% disseminated intravascular coagulation (DIC), $20 \%$ infection, $15 \%$ relaparatomy and $5 \%$ was pulmonary embolism. The reason for all patients with maternal death was DIC and multiple organ failure. We know the primary cause of this was bleeding. A statistically significant negative $-0.772(\mathrm{p}=0.01)$ correlation was observed between maternal mortality and postoperative HGB values. A statistically significant positive correlation was observed between ES transfusion and maternal mortality $(0,562(\mathrm{p}=0,01))$. We think that a massive transfusion does not decrease mortality. In deepening cases of invasion, the bladder was perforated iatrogenically and assisted in the anatomical separation of tissues with a ureter catheter inserted from the bladder. The posterior bladder wall bleeds a lot during the operation due to the excessive blood supply at the depth of the invasion [19]. In hemorrhages in this area, when the area is large and the bleeding control becomes difficult, posterior bladderwall resection is performed without wasting time. Surgical procedures in this area appear as fistulas as a long-term complication [20]. While AIP cases in another region with a high birth rate in our country are routinely taken to the intensive care unit after the operation [20], only the patients $(55 \%(n=11))$ that anesthesiologists deem necessary are taken into intensive care in our hospital.

When the newborn findings were examined, the average gestational age was found to be $36 \pm 2,434$ (30-39) weeks. Accordingly, many studies suggest that preterm $\mathrm{C} / \mathrm{S}$ should be performed between $340 / 7$ and 356/7 weeks in order to eliminate the risk of bleeding during surgery and thus reduce the rate of maternal morbidity and mortality $[19,21]$. The advanced

Table 5. Demographic characteristics, complications and surgery data of 5 cases with mortality

\begin{tabular}{|c|c|c|c|c|c|c|c|c|c|c|}
\hline $\begin{array}{l}\text { Age } \\
\text { (years) }\end{array}$ & $\begin{array}{l}\text { Existence } \\
\text { of risk } \\
\text { factors }\end{array}$ & $\begin{array}{l}\text { POG } \\
\text { (weeks) }\end{array}$ & $\begin{array}{l}\text { Preop } \\
\mathrm{Hb} \\
(\mathrm{gr} / \mathrm{dl})\end{array}$ & $\begin{array}{l}\text { Sonographically } \\
\text { diagnosed }\end{array}$ & $\begin{array}{l}\text { Elective/ } \\
\text { emergency }\end{array}$ & Surgery & USG & $\begin{array}{l}\text { Postop } \\
\text { complications }\end{array}$ & $\begin{array}{l}\text { Blood } \\
\text { Transfusion }\end{array}$ & $\begin{array}{l}\text { ICU stay } \\
\text { (days) }\end{array}$ \\
\hline 41 & yes & 38 & 11,7 & yes & emergency & TAH, HAL, & yes & dic & $\begin{array}{l}10 \mathrm{ES} \\
15 \mathrm{FFP}\end{array}$ & 30 \\
\hline 46 & yes & 36 & 7,07 & yes & emergency & TAH, HAL, & yes & dic & $\begin{array}{l}10 \mathrm{ES} \\
9 \mathrm{FFP}\end{array}$ & 8 \\
\hline 41 & yes & 39 & 10,2 & no & emergency & TAH, HAL, & no & dic & $\begin{array}{l}\text { 13ES } \\
16 \mathrm{FFP}\end{array}$ & 25 \\
\hline 30 & none & 36 & 11,5 & yes & emergency & TAH, HAL, $2^{\text {th }}$ OPR. & yes & Dic +sepsis & $\begin{array}{l}8 \mathrm{ES} \\
9 \mathrm{FFP}\end{array}$ & 12 \\
\hline 34 & yes & 36 & 11,9 & yes & elective & TAH, HAL, $2^{\text {th }}$ OPR. & yes & Dic+sepsis & $\begin{array}{l}6 \mathrm{ES} \\
6 \mathrm{FFP}\end{array}$ & 17 \\
\hline
\end{tabular}


gestational week of our cases was attributed to the waiting of the delivery time of patients who could not be diagnosed with percreata. In our study, fetal mortality was not observed, it was found that birth weights were normal compared to the gestational week, but the APGAR score at the first and fifth minutes were lower than normal and were compatible with other studies [22].

Ultrasound is usually the primary tool for evaluating women at risk of AIP, such as patients with placenta previa and previous $\mathrm{C} / \mathrm{S}$, while MRI is performed only to confirm the diagnosis or in the event of an inconclusive ultrasound evaluation [23]. The diagnostic values of the two imaging methods were determined to be the same [24]. In previous studies, it was reported that early diagnosis in ultrasonography decreased maternal mortality and blood product transfusion needed [25]. In cases diagnosed before the operation, $85 \%(\mathrm{n}=$ 17) maternal mortality was observed to decrease (OR: 0.615). In our study, an emergency operation was seen as another important reason for increasing mortality (OR; 4,784) [26]. In our cases, adjacent organ invasion was observed as $60 \% \quad(\mathrm{n}=12)$ and maternal mortality increased by 3.4 times (OR; 3.496) if adjacent organ invasion was observed. Therefore, diagnosis and taking precautions with prenatal imaging may decrease maternal mortality.

The fact that the number of cases were low and the conservative approach was rather limited due to the previous maternal losses were found to be limitations of our study.

As a result, the incidence of placenta acreta increases with the $\mathrm{C} / \mathrm{S}$ rate. It is important for a prenatal diagnosis of percreta cases and operation of cases under elective conditions in terms of decreasing maternal mortality. The postoperative hemoglobin value may be important in terms of both hemorrhage estimation and mortality and prognosis. Although there are various surgical complications, we think that DIC development is effective in mortality and that adequate and timely blood transfusion is important instead of a massive transfusion.

\section{References}

1. Chan B, Lam H, Yuen J, et al. Conservative management of placenta praevia with accreta. Hong Kong Med J. 2008;14(6):47984.

2. Gielchinsky Y, Rojansky N, Fasouliotis S, et al. Placenta accreta-summary of 10 years: a survey of 310 cases. Placenta. 2002;23(2-3):210-214

3. Jauniaux E, Bunce C, Grønbeck L, et al. Prevalence and main outcomes of placenta accreta spectrum: a systematic review and metaanalysis. Am J Obstet Gynecol. 2019.

4. Miller DA, Chollet JA, Goodwin TM. Clinical risk factors for placenta previa-placenta accreta. Am J Obstet Gynecol. 1997;177(1):210-214.

5. Ye J, Zhang J, Mikolajczyk R, et al. Association between rates of caesarean section and maternal and neonatal mortality in the 21st century: a worldwide population-based ecological study with longitudinal data. BJOG. 2016;123(5):745-753.

6. Clausen C, Lönn L, Langhoff-Roos J. Management of placenta percreta: a review of published cases. Acta Obstet Gynecol Scand. 2014;93(2):138-143.

7. Cim N, Elci E, Sayan S, et al. Trends and causes of maternal mortality in Eastern province of Turkey. Eastern Journal Of Medicine. 2017;22(4):191.

8. Chantraine F, Braun T, Gonser M, et al. Prenatal diagnosis of abnormally invasive placenta reduces maternal peripartum hemorrhage and morbidity. Acta Obstet Gynecol Scand. 2013;92(4):439-444.

9. Wh TE. Ultrasonographical features of morbidly-adherent placentas. Singapore Med J. 2007;48(9):799-803.

10. Wortman AC, Alexander JM. Placenta accreta, increta, and percreta. Obstetrics and Gynecology Clinics. 2013;40(1):137-154.
11. Matsuzaki S, Yoshino K, Endo $M$, et al. Conservative management of placenta percreta. International Journal of Gynecology \& Obstetrics. 2018;140(3):299-306.

12. Yu P-C, Ou H-Y, Tsang LL-C, et al. Prophylactic intraoperative uterine artery embolization to control hemorrhage in abnormal placentation during late gestation. Fertil Steril. 2009;91(5):1951-1955.

13. Kilicci C, Ozkaya E, Eser A, et al. Planned cesarean hysterectomy versus modified form of segmental resection in patients with placenta percreta. The Journal of Maternal-Fetal \& Neonatal Medicine. 2018;31(22):2935-2940.

14. Iwata A, Murayama Y, Itakura A, et al. Limitations of internal iliac artery ligation for the reduction of intraoperative hemorrhage during cesarean hysterectomy in cases of placenta previa accreta. J Obstet Gynaecol Res. 2010;36(2):254-259.

15. Eller A, Porter T, Soisson P, et al. Optimal management strategies for placenta accreta. BJOG. 2009;116(5):648-654.

16. O'Brien JM, Barton JR, Donaldson ES. The management of placenta percreta: conservative and operative strategies. Am J Obstet Gynecol. 1996;175(6):1632-1638.

17. Shrivastava V, Nageotte M, Major C, et al. Case-control comparison of cesarean hysterectomy with and without prophylactic placement of intravascular balloon catheters for placenta accreta. Am J Obstet Gynecol. 2007;197(4):402. e1-402. e5.

18. Camuzcuoglu A, Vural M, Hilali NG, et al. Surgical management of 58 patients with placenta praevia percreta. Wien Klin Wochenschr. 2016;128(9-10):360-366.

19. Sak S, Barut M, Incebiyik A, et al. Management of peripartum hysterectomies performed on patients with placenta percreta in a tertiary central hospital. J Matern Fetal Neonatal Med. 2019 Mar;32(6):883-888.

20. D'antonio F, Palacios-Jaraquemada J, Lim P, et al. Counseling in fetal medicine: evidence-based answers to clinical questions on morbidly adherent placenta. Ultrasound Obstet Gynecol. 2016;47(3):290-301.

21. Obstetricians ACo, Gynecologists. ACOG committee opinion no. 560: Medically indicated late-preterm and early-term deliveries. Obstet Gynecol. 2013;121(4):908.

22. Lal AK, Hibbard JU. Placenta previa: an outcome-based cohort study in a contemporary obstetric population. Arch Gynecol Obstet. 2015;292(2):299-305.

23. Riteau A-S, Tassin M, Chambon G, et al. Accuracy of ultrasonography and magnetic resonance imaging in the diagnosis of placenta accreta. PLoS One. 2014;9(4).

24. Lopes ES, de Lucena Feitosa FE, Brazil AV, et al. Assessment of sensitivity and specificity of ultrasound and magnetic resonance imaging in the diagnosis of placenta accreta. Revista Brasileira de Ginecologia e Obstetrícia/RBGO Gynecology and Obstetrics. 2019;41(01):017-023.

25. Chantraine F, Braun T, Gonser M, et al. Prenatal diagnosis of abnormally invasive placenta reduces maternal peripartum hemorrhage and morbidity. Acta Obstet Gynecol Scand. 2013 Apr;92(4):439-44.

Allam IS, Gomaa IA, Fathi HM, et al. Incidence of emergency peripartum hysterectomy in Ain-shams University Maternity Hospital, Egypt: a retrospective study. Arch Gynecol Obstet. 2014 Nov;290(5):891-6. 